\author{
Elżbieta Osewska* \\ Cardinal StefanWyszynski University in Warsaw, Poland
}

\title{
The Basic Assumptions of Child Upbringing in the Family. Modern Implications
}

The process of upbringing within the family is dependent upon various factors, which derive from the family itself (the family relations and their many-faceted determinants), but also from the outside, especially as far as personal and social development is concerned. The achievement of the common good, as well as the individual good, of all the family members requires that all of them share the

* ELŻBIETA OSEWSKA - Associate Professor of Theology in the field of Catechetics and Family Studies. M.A. in Theology, S.T.L. in Pastoral Theology, Ph.D. in Theology in the field of Pastoral Theology at the Catholic University in Lublin (dissertation: "Modern Family Catechesis. Pastoral and Catechetical Studies"), then the habilitation in Theology in Catechetics at Cardinal Stefan Wyszynski University in Warsaw (dissertation: "Religious Education in Catholic Schools in the Light of Living and Sharing our Faith. A National Project of Catechesis and Religious Education"). 1990-1993 - lecturer in catechetical centers in Belarus, Lithuania, Latvia. 1998-1999 - Head of the Department of Family Affairs in the Chancellery of the Prime Minister in Warsaw. She is also an RE consultant in the Provincial In-service Centre in Lomza. A member of the Society the European Catechetical Equips, the European Society of Catholic Theology (vice-president of Polish section); the European Forum for Religious Education, Polish Familiology Association (vice-president), Society of Professors and Lecturers in Catechetics. She is also a member of the Polish Accreditation Committee (PKA) in two sections: Humanities and Theological Science Section; Section for Ethics. Participant and organizer of many conferences, symposiums and congresses in Poland and abroad. Co-author and editor of many RE textbooks. Her field of interests include the catechetics, pedagogy, religious education in Catholic schools, family catechesis, practical theology, didactics, family policy, communication and ICT. She has published a number of articles and books on related topics. 
same system of values, feel part of and are willing to contribute to the community and are determined to abide in it. It also requires that good rearing practices are initiated and consistently implemented throughout the upbringing process. The Polish family of the $21^{\text {st }}$ century, although it is aware of the key role it must play in the process of child upbringing, experiences a serious discrepancy between the ideal upbringing and the everyday life experience, between the multigenerational upbringing tradition and the excessive liberalism in upbringing which is promoted by media, between the model in which the parents play an important role in child upbringing and naturalism.

Whereas the traditional upbringing model expressed the asymmetrical relation, which was based on the accepted authority of the parents, the subsequent paidocentrism has favoured the child and his/her needs, desires and expectations, granting the child the central position in the upbringing process. The approval of shaping, moulding, often manipulation of the child has been replaced by the other extreme: excessive emphasis on the central position of the child, which sometimes leads to absurdity. Nowadays parents, guardians and grandparents feel confused by the proposed upbringing styles and practices. Whilst the earlier generations learnt how to cope with the, forcibly imposed, communist or socialist ideals, minimizing their impact on the family, the current generation of parents faces a medley of confusing postmodern upbringing propositions and pseudo-propositions. In addition, the development of highly specialised educational institutions offers a seemingly simply solution: the upbringing process should be transferred from the family to those educational institutions.

In this article upbringing within the family will be treated as a permanent proposition which implies an active role of adults (parents, guardians, grandparents, relatives) who accompany, support and bring up the child. It is based on dignity, freedom, and respect for all the participants of the upbringing process and the recognition of the basic, primary, inalienable right of the family to carry out the upbringing process ${ }^{1}$. Therefore the first part of the article presents the guidelines of the Catholic Church concerning child upbringing in the family, followed by the basic assumptions of child upbringing in the family, which take into consideration various aspects of the process.

$1 \quad$ Familiaris Consortio 36. 


\section{The guidelines of the Catholic Church concerning child upbringing in the family}

Upbringing is commonly defined as an aid in the full development of the child, in his/her becoming an adult. It is a holistic process, although it possible to distinguish some parts depending on what specifically refers to this help. Declaration on Christian Education Gravissimum Educationis states: "All men of every race, condition and age, since they enjoy the dignity of a human being, have an inalienable right to an education that is in keeping with their ultimate goal, their ability, their sex, and the culture and tradition of their country, and also in harmony with their fraternal association with other peoples in the fostering of true unity and peace on earth. For a true education aims at the formation of the human person in the pursuit of his ultimate end and of the good of the societies of which, as man, he is a member, and in whose obligations, as an adult, he will share"2. Therefore the core of upbringing and its basic aim means shaping the personality of the human person up to his/her full and integral development. Education is a fundamental right of all people in the view of their human dignity, their role in the society and the Church, but also their eternal destiny.

The right of the person to be brought up is complementary to the right to undertake education by parents, grandparents, guardians. In the Church documents, parents are recognised as the primary educators of their children. They are not only obliged to educate their children, but first of all, mothers and fathers have the right and privilege to initiate and continue the process of upbringing within the family. As early as 1929, in the Encyclical Divini Illius Magistri, Pope Pius XI stated the right of the family to educate : "The first natural and necessary element in this environment, as regards education, is the family, and this precisely because so ordained by the Creator Himself. Accordingly that education, as a rule, will be more effective and lasting which is received in a well-ordered and well-disciplined Christian family; and more efficacious in proportion to the clear and constant good example set, first by the parents, and then by the other members of the household"3.

The right of the family to educate has been repeated by Fathers of the Second Vatican Council: "Since parents have given children their life, they are bound by the most serious obligation to educate their offspring and therefore must be recognized as the primary and principal educators. This role in education is so important that

2 Gravissimum Educationis 1.

3 Divini Illius Magistri 71. 
only with difficulty can it be supplied where it is lacking. Parents are the ones who must create a family atmosphere animated by love and respect for God and man, in which the well-rounded personal and social education of children is fostered. Hence the family is the first school of the social virtues that every society needs" ${ }^{\text {. }}$ The Second Vatican Council documents, especially the Declaration Gravissimum Educationis has been concerned more than Divini Illius Magistri to present the education in the perspective of human dignity and to spell out the holistic view of basic educational principles. Gravissimum Educationis emphasises the essential role of family in promoting the life and development of children. "The family is a kind of school of deeper humanity. But if it is to achieve the full flowering of its life and mission, it needs the kindly communion of minds and the joint deliberation of spouses, as well as the painstaking cooperation of parents in the education of their children"5. According to the Vatican documents the active presence of both parents at home and their cooperation is highly beneficial to their children upbringing.

The concept of the family as the primary setting for education has been announced and enriched effectively by Pope John Paul II, especially in his exhortation on family, Familiaris Consortio, letter to the families Gratissimam Sane and Charter of the Rights of the Family. Pope John Paul II underlined the right of family for education and connected the child upbringing in the family with the idea of love and community: "The right and duty of parents to give education is essential, since it is connected with the transmission of human life; it is original and primary with regard to the educational role of others, on account of the uniqueness of the loving relationship between parents and children; and it is irreplaceable and inalienable, and therefore incapable of being entirely delegated to others or usurped by others" ${ }^{\text {. }}$. Despite many present challenges "the family constitutes, much more than a mere juridical, social and economic unit, a community of love and solidarity, which is uniquely suited to teach and transmit cultural, ethical, social, spiritual and religious values, essential for the development and well-being of its own members and of society"7.

The subject of upbringing in the family has been also taken into consideration in catechetical documents, for example General Catechetical Directory reminds that "The first roots of religious and moral life appear at the very beginning of human life. In the families of believers, the first months and years of life, which are of the

4 Gravissimum Educationis 3.

5 Gaudium et Spes 52.

6 Familiaris Consortio 36.

7 Charter of the Rights of the Family Preamble. 
greatest importance for a man's balance in the years to come, can already provide the right conditions for developing a Christian personality" ${ }^{\text {. In turn, the General }}$ Directory for Catechesis devotes one part to the education in the family and calls the family community - a locus of catechesis. "The family has a unique privilege: transmitting the Gospel by rooting it in the context of profound human values. On this human base, Christian initiation is more profound: the awakening of the sense of God; the first steps in prayer; education of the moral conscience; formation in the Christian sense of human love, understood as a reflection of the love of God the Father, the Creator"'.

Official Church teaching has consistently reaffirmed the importance of children upbringing within the family. The Catechism of the Catholic Church teaches "Parents have the first responsibility for the education of their children. They bear witness to this responsibility first by creating a home where tenderness, forgiveness, respect, fidelity, and disinterested service are the rule. The home is well suited for education in the virtues. This requires an apprenticeship in self-denial, sound judgment, and self-mastery - the preconditions of all true freedom"10. According to catechetical documents, education within the family is based on love and witnessing the virtues, connected with daily life and personal development of every member of the family.

\section{Basic assumptions of child upbringing in the family}

Some parents feel discouraged, helpless and confused by secularism and cultural pluralism. As a result, they try to transfer the responsibility for their children's upbringing to specialist institutions (schools, sport clubs, children and youth organisations), but none of them is able to recreate the bonds of love, community, the sense of security and intimacy characteristic of the family. Yet, the family as a community does not come into being solely on the basis of a social contract: it is firmly rooted in the human nature. As a community, it requires that its members, primarily parents or guardians, undertake consistent activities for the sake of love and education.

It is in the family environment that the child's life begins and develops on all levels and the beginning of life to a great extent determines the child's future. The

$8 \quad$ General Catechetical Directory 78.

9 General Directory for Catechesis 255.

10 Catechism of the Catholic Church 2223. 
impact of the parents and the family environment endures throughout one's life. In this way, the child is equipped with "a psychological and spiritual dowry", s/he will draw on as an adult. Even if parents and guardians love their children, wish them well and want to participate in their upbringing, they sometimes cannot prevent, heal or overcome difficulties, having been themselves exposed to bad examples in their own family environment or seeking guidance on the Internet or in tabloids. Young, inexperienced mothers in the $21^{\text {st }}$ century lack the support of elder women, which the generations of their mothers and grandmothers used to have. Not a long time ago, in many families, the young mother, especially the primigravida, was cared for by other women, especially her mother, grandmothers, cousins, who not only taught her basic child care activities, gave her advice concerning child upbringing, allowed her to have a rest, but also on the basis of their own experience recognized her emotional, social, spiritual needs and offered support. Thanks to them, the young mother interacted with the extended family. It is worthwhile then to indicate the basic good rearing practices, which enable parents and guardians to raise their wards in a responsible and mature way.

The first assumption may seem surprisingly simple, as it points to the necessity of the parents' presence in the child's everyday life. In the period of sociocultural change, which has been taking place in Poland since 1989, there has been an increase in the number of dysfunctional families, in which emotional bonds between family members have been loosened, in which less time is spent together due to focus on the accumulation of material goods. There are more and more children who are afflicted with a sense of loneliness, despite the apparent physical presence of the family. They are not necessarily abandoned, but suffer because the emotional ties are weak or severed. It is more and more the case that the parents do not share the child's experiences and do not offer him/her sufficient support, which results in the child's feeling insecure, distrustful and lonely ${ }^{11}$. The term 'loneliness' may have many meanings, yet for a child, who has not yet developed his/her own inner world, it means an enormous burden, which can adversely affect his/her psyche ${ }^{12}$. Lack of contact with oneself, with one's siblings, parents and other people contradicts the rules of good child upbringing.

11 See M. Grzywak-Kaczyńska, Wychowanie do miłości - miłości trzeba się uczyć, in: Wychowanie personalistyczne, ed. F. Adamski, Kraków 2003, p. 363-375; J. Homplewicz, Pedagogika rodziny, Rzeszów 2000; S. Kawula, J. Brągiel, A. Janke, Pedagogika rodziny. Obszary i panorama problematyki, Toruń 2000.

12 See J. Mastalski, Samotność globalnego nastolatka, Kraków 2007. 
The second condition is the parents' mutual love. The relationship between the spouses as well as the process of the levelling of personality differences shape the psychological identity of each family, its unity of feeling, thought and activity. The unique organisation of the family with its system of family relationships is built on the basis of the love between the spouses ${ }^{13}$. It is only in the context of the visible and mature conjugal love that the children may discover that they are loved by their parents. Family love is grounded in the father's love for the mother manifested in respect, help in everyday life, words and gestures as well as the mother's love for the father expressed by means of a smile, tenderness and housework. In contrast, when the parents are at odds, hurting each other, their children are full of anxiety, intimidated, or aggressive. Even if one of the parents goes out of their way to express tenderness and interest in their children, the situation will not improve dramatically. Children feel loved, safe and precious only within the mutual love of their parents. Happy conjugal relationship is dependent upon the spouses' physical and emotional maturity, which is achieved gradually by each individual. Emotional stability, respect for the spouse, readiness to sacrifice oneself for the sake of the spouse, openness, self-esteem, satisfaction with one's work contribute to the loving relationship and happiness in marriage ${ }^{14}$.

The third condition is the recognition of parents as significant persons who are responsible for the process of child upbringing. Parents give their child life together with the genetic make-up and, especially in the initial stage of the child's life, 'create his world'. The younger the child, the more dependent he is on his parents for the satisfaction of his needs. Gradually, as the child becomes more and more self-reliant and independent, the parents cater less and less for the child's needs ${ }^{15}$. In infancy they cater for the basic needs and teach all the activities, later they become more of confidants and advisors. In puberty they help their children to become responsible, to find and shape their own personalities. On the threshold of adulthood they move to the background but still accompany their children. Both the mother and the father are significant persons in the process of child upbringing, nevertheless their roles differ. The girl learns the role of a woman from

13 M. Ryś, Psychologia rodziny, in: Rodzina. Bezcenny dar i zadanie, eds. J. Stala, E. Osewska, Radom 2006, p. 332-333.

14 See B. Mierzwiński, Szczęście w małżeństwie - mit czy rzeczywistość?, "Katecheta" 41 (1997) No. 3; M. Ryś, Psychologia rodziny, in: Rodzina. Bezcenny dar i zadanie, eds. J. Stala, E. Osewska, Radom 2006, p. 366-371.

15 K. Appelt, Rodzice - osoby znaczące w rozwoju człowieka, "Remedium” (2004) No. 12, p. 4-5. 
her mother; the boy learns to be a man by watching his father. Both parents play important roles in the process of child upbringing.

Another important assumption underlying the process of child upbringing within the family is also the recognition of the value of the child as the subject of the process. In the traditional multigenerational family the children were looked upon with pride and their number reinforced the social standing of the family; today children are dependent on the parents for financial help for much longer, not only due to the prolonged education period, but also due to difficulties on the labour market. This reinforces the conviction that the child is but a burden on the family ${ }^{16}$. The development of secular views of humanity, legal positivism and ethical liberalism in the recent decades in Poland has violated the ethical and religious norms protecting human life, which has a direct bearing on the perception of the child's value. The view of the child as a continuation of the family, provision for old age and a means of strengthening the family is on the wane. In the traditional Polish family the child was considered as a gift from God to be received with gratitude. Due to the socio-cultural transformations, as well as the development of medicine, the child has come to be regarded more as the fruit of conjugal love, dream fulfilment or even an 'exclusive product' which is meant to fulfil the parents' needs and aspirations. The religious vision that the child is a result of the parents' cooperation with the Creator is in decline. It is being replaced by the secular view that it is the parents who want the child and accept it with love when it is desired, or reject it when it has not been 'planned' ${ }^{17}$. The child is seen as the fulfilment of the parents' wish. When it is wanted, it becomes a 'precious product', viewed as belonging to the parent's category of pleasure. When it is not wanted, it becomes a 'redundant' and expensive burden for the parents. The view of a child as the fulfilment of the parents' dreams, or merely the fulfilment of paternity or maternity needs, is very dangerous. With such a view the parents very often limit the family to the ' $2+1$ model', believing that one child suffices, and the next child may be seen as an obstacle to the professional career, the pursuit of personal interests or social life. In such a case it is easy to forget that a child is a person who should

16 See J. Laskowski, Małżeństwo i rodzina, Warszawa 1982, p. 12, 23; II Polski Synod Plenarny, Projekt dokumentu końcowego, Małżeństwo i rodzina w Kościele i w społeczeństwie, "Kurier Synodalny" 46-47 (1998) No. 1-2, p. 23.

17 See II Polski Synod Plenarny, Projekt dokumentu końcowego, Małżeństwo i rodzina w Kościele i w społeczeństwie, "Kurier Synodalny" 46-47 (1998) No. 1-2, p. 35-36. 
be accompanied in the process of growing up by the parents as wise and reliable guardians, advisors, educators and examples to follow.

The process of upbringing should be based on the assumption that all the participants deserve respect, appreciation of their intelligence, freedom and conditions conducive to the knowledge of truth, the pursuit of good, the discovery of beauty and self-fulfilment, in the service others within the community of the family. The respect for one's relatives should spread to include all people as well as oneself and God until the moral stance of unconditional love for all mankind is achieved, where one cares for the good of other human beings as well as the common good. All human beings must be treated with respect as persons. It concerns children and parents as well as grandparents, both the healthy and the ill, the happy and the sad, but the most vulnerable must be given the priority: children in the prenatal phase, physically and mentally disabled people as well as people with mental disorders.

\section{Pedagogical and cultural assumptions of the process of child upbringing in the family}

The next good rearing practice is the setting of common goals in the family ${ }^{18}$. Mature, responsible and loving parents set the pedagogical goals together. They realize that the ultimate goal, that is, the preparation of their child for adult life, the shaping of a wise and honest person and the formation of a good Christian, requires everyday pursuit of many smaller goals ranked differently in the order of importance. The ultimate goals should be set with prudence and should reflect the overall realistic assessment of the child, his/her potential, as well as limitations and the future tasks. In order to assist the child in shaping his/her personality the parents must recognize what matters in life for them, what they wish for their child and how they envision their child's future. Good upbringing is based on

18 Religious Education / Catechesis in the Family. A European Perspective, eds. E. Osewska, J. Stala, Warszawa 2010; Nauki o rodzinie w stużbie rodziny, ed. J. Stala, Kraków 2014; J. Stala, Der Mensch als Person: Die bestimmende Grundlage für Johannes Paul II. in seinem Bild von der Familie, "The Person and the Challenges" 2 (2012) nr 2, p. 41-59; E. Osewska, J. Stala, Założenia i uwarunkowania wychowania religijnego podejmowanego w środowisku rodzinnym, in: Wychowanie do wartości w świecie cyberkultury, ed. B. Bilicka, Toruń 2012, p. 183-214; J. Stala, Der gesellschaftlich-kulturelle Kontext der aktuellen Gefährdungen für die religiöse Erziehung und Bildung in der Familie, "The Person and the Challenges" 3 (2013) nr 1, p. 251-266. 
freedom, wisdom and love, because to become a mature person, one must be free, one must learn to use one's freedom wisely and learn to love oneself, other people and God. Freedom, wisdom and love are the values which should be considered as top priorities in the process of child upbringing. Responsible parents must not only set the right goals, but they must be consistent in their pursuit.

The relations between the child and the parents are very dynamic. The child behaves according to the attitudes and the actions of the mother and the father; the parents, in turn, change in response to the child. The development of the child requires that the parents or guardians undertake various forms of care and educational methods. That is why the next condition for successful upbringing is the need to choose and use adequate methods. The correctly exerted influence of the parents upon the child is conducive to the unity of the family; in contrast, incorrect, impoverished parental attitudes make the bonds weaken or even disappear. The basic rule here is: use positive motivation. The process of upbringing is not successful if it is based on punishment, orders, bans, threats, control and coercion. Positive motivation, which is inculcated through wise influence of the parents and their talks with the children, makes the children discover that following parental precepts does not mean coercion but a way to maturity. A good rearing practice is respectful communication between the parents and the children, which consists in listening to the other party as well as clear expression of one's observations, thoughts, feelings and needs. Parents should make reasonable demands of their children according to their age and abilities as the rearing process aims at shaping mature attitudes, behaviour and choices. It is impossible without making effort, without forgoing instant gratification, without inner discipline and self improvement. A corollary to the demands is reasonable but firm disciplining if the children have made mistakes, for child upbringing includes teaching the correlation between a behaviour and its consequences. Mature parents would not let their children presume that they may become happy and valuable persons despite being aggressive, mendacious and lazy.

The process of upbringing in the family must encompass all the aspects of the human being: his sensuality and physicality, his intellect and will, his emotions as well as the social, moral, spiritual and religious spheres. Integrity is the next fundamental assumption of good upbringing. An integral approach to children safeguards their full, harmonious development, which leads to the consistency of thoughts, words and actions. If the process of child upbringing is too one-sided, if the parents focus excessively on one sphere or disregard some aspect, no good intentions or plans will help to achieve the desired effect. The integral approach does not limit upbringing to one sphere, e. g. the intellect, but it appreciates all the aspects of the child's personality. A harmonious upbringing involves not only 
comprehensive formation of the child's personality but also consistency of parental teaching. A child is gradually introduced into the world of the family culture, and the totality of human culture according to his age and ability. Acquiring that knowledge, the child also learns to evaluate, choose what is valuable and reject what is worthless as well as avoid what is dangerous. As a community of love, selflessness, respect, loving kindness, the family enables the child to reach full personal, social and axiological maturity. The child first discovers a value and its presence, experiences it emotively and then fully comprehends it. In this way, through informed decision, experience and implementation in real life, the value is gradually inculcated until it is permanently interiorized. This personalistic process of child upbringing, based on the relationship between the child and his/her parents as well as all the other relatives who constitute the rearing community, may seem somewhat utopian if juxtaposed with the reality of contemporary family life. Yet, it is indispensable for the family, society and nation to function properly.

The comprehensive development of the child in the family requires a good atmosphere, which depends to a great extent on the level of the culture of life, feelings, spiritual and religious life as well as the material conditions. The atmosphere of warmth, care, generosity, respect, safety as well as security, order, harmony, justice, joy and freedom inspires the child's trust in oneself, other people and the world. Its lack, in turn, brings about anxiety and insecurity because the family is too malleable when exposed to external stimuli and, as a result, easily loses its original character.

Each family has its own heritage which is linked with the culture of the region and the nation. This creates both opportunities and dangers. It is especially alarming that the so-called mass culture, propagated by the mass media, undermines parental authority, shows the traditional Christian rules and values as relative, thus creating chaos in the rearing system ${ }^{19}$. It is worthwhile then to point to the essential elements of the spiritual culture of the family: words, symbol sensitivity, customs and rituals and the hierarchy of values ${ }^{20}$. Words exchanged by the family members are very important, as they accompany everyday life situations. Everyday experience of family life needs to be completed and interpreted by means of words. Unfortunately, current socio-cultural changes, especially the development of the Information and Communications Technology contributes to the deterioration of the verbal culture. The increasing pace of life impairs the scope and complexity of verbal communication at home. People read less, and as a result, their language is

19 See Dyrektorium katechetyczne Kościoła katolickiego w Polsce, Kraków 2001, no 7.

20 See J. Wilk, Pedagogika rodziny. Zagadnienia wybrane, Lublin 2002, p. 67-79. 
impoverished. Everyday exchange of news, stories as well as the custom of reading books together is on the decline. Proper upbringing should sensitize the child to the presence of signs and symbols, especially the symbols whose meaning has a spiritual and religious dimension such as: a table, bread, water, a handshake, a smile. The family which is able to sensitize the children and adults to the world of symbols, which encourages admiration and a sense of wonder not only brings home the deep meaning of those symbols, but also helps man discover the depth, purpose and meaning of life.

The characteristic feature of the Polish family is the richness of ritual, which is permeated by patriotism and religion. Family ritual plays an important role in the process of child upbringing, that is why families which cultivate their traditions are closer-knit and joyful. Their religiosity is natural and the religious education they provide more lasting. Unfortunately, since Poland joined the EU, Polish traditions, customs, religious and patriotic rituals have been disregarded for the sake of quasi-Europeanization. It is the family that protects the child and passes down a certain hierarchy of values to the next generations, which is especially vital in today's pluralistic society, because the family which has a clearly defined system of values teaches the child to develop his/her hierarchy of values and creates a 'value filter', which enables the child to reject pseudo-values.

In order to raise the child, the parents or guardians must make some assumptions and set clear goals based on their own hierarchy of values, tradition or religion. The basic conditions for the properly carried out process of child upbringing include: the caring presence of the parents, their mutual love, the acknowledgement of the child's importance and dignity, as well as the dignity of all the family members, the acceptance of the role of the parents as educators, the choice of goals and methods, the creation of a good atmosphere and the spiritual culture of the family. The pursuit of man's full, integral development enables the family to undertake an upbringing process which is focused, not only on the individual child, but fosters the self-development of the other family members and their pursuit of values. In order to overcome the disparity between the traditional view of child upbringing and the conceptions promoted in the $21^{\text {st }}$ century, it is crucial that the parents realize and implement the basic rules which are conducive to the integral formation of the child as a person. 


\section{Bibliography}

Gatt S., Lombaerts H., Osewska E., Scerri A., Catholic Education, European and Maltese Perspectives. Church School's response to future challenges, Floriana 2004.

Nauki o rodzinie w służbie rodziny, ed. J. Stala, Kraków 2014.

Osewska E., L'educazione oggi in un'Europa diversificata, in: Europa, scuola, religioni. Monoteismi e confessioni cristiane per una nuova cittadinanza europea, ed. F. Pajer, Torino 2005, p. 47-64.

Osewska E., Możliwości i ograniczenia polityki rodzinnej w krajach Unii Europejskiej, in: Rodzina jako środowisko rozwoju człowieka, ed. W. Piotrowski, Tarnów 2004, p. 89-119.

Osewska E., Stala J., Założenia $i$ uwarunkowania wychowania religijnego podejmowanego $w$ środowisku rodzinnym, in: Wychowanie do wartości w świecie cyberkultury, ed. B. Bilicka, Toruń 2012, p. 183-214.

Religious Education / Catechesis in the Family. A European Perspective, eds. E. Osewska, J. Stala, Warszawa 2010.

Rodzina w trosce o życie - Kościół w trosce o rodzinę, ed. R. Buchta, Katowice 2010.

Rodzina. Bezcenny dar i zadanie, ed. J. Stala, E. Osewska, Radom 2006.

Stala J., Der gesellschaftlich-kulturelle Kontext der aktuellen Gefährdungen für die religiöse Erziehung und Bildung in der Familie, "The Person and the Challenges" 3 (2013) nr 1, p. 251-266.

Stala J., Der Mensch als Person: Die bestimmende Grundlage für Johannes Paul II. in seinem Bild von der Familie, “The Person and the Challenges" 2 (2012) nr 2, p. 41-59.

Stala J., Familienkatechese in Polen um die Jahrhundertwende. Probleme und Herausforderungen, Tarnów 2008.

Stala J., Katecheza o małżeństwie i rodzinie w Polsce po Soborze Watykańskim II. Próba oceny, Tarnów 2004.

Stala J., W kierunku integralnej edukacji religijnej w rodzinie. Próba refleksji nad nauczaniem Jana Pawła II w kontekście polskich uwarunkowań, Tarnów 2010.

Stinnett N., DeFrain J., Secrets of Strong Families, Boston 1985.

The European Family. The Family Questions in the European Community, ed. J. Commaille, F. de Singly, Dordrecht-Boston-London 1997.

Wilk J., Pedagogika rodziny. Zagadnienia wybrane, Lublin 2002. 